\title{
James v. Valtierra: Housing Discrimination by Referendum?
}

If the poor want the affluent to provide them with housing, it would seem only reasonable that they should expect and be willing to accept the willing consent of a simple majority of those persons who are expected to help pay ....

Wherever the real power in a Government lies, there is the danger of oppression. In our Government the real power lies in the majority of the Community, and the invasion of private rights is chiefly to be apprehended, not from acts of Government contrary to the sense of its constituents, but from acts in which the Government is the mere instrument of the major number of the constitutents. This is a truth of great importance, but not yet sufficiently attended to.... ${ }^{2}$

In James v. Valtierra ${ }^{3}$ the United States Supreme Court upheld the constitutionality of article XXXIV of the California Constitution, ${ }^{4}$

1 Brief for Appellants James et al. at 17-18, James v. Valtierra, 402 U.S. 137 (1971).

25 Writings of James Madison 272 (Hunt ed. 1904).

3402 U.S. 137 (1971).

4 CAL. Const. art. XXXIV, \& I provides:

No low rent housing project shall hereafter be developed, constructed, or acquired in any manner by any state public body until, a majority of the qualified electors of the city, town or county, as the case may be, in which it is proposed to develop, construct, or acquire the same, voting upon such issue, approve such project by voting in favor thereof at an election to be held for that purpose, or at any general or special election.

For the purposes of this article the term "Iow rent housing project" shall mean any development composed of urban or rural dwellings, apartments or other living accommodations for persons of low income, financed in whole or in part by the Federal Government or a state public body, or to which the Federal Government or a state public body extends assistance by supplying all or part of the labor, by guaranteeing the payment of liens, or otherwise .... .

For the purposes of this article only "persons of low income" shall mean persons or families who lack the amount of income which is necessary (as determined by the state public body developing, constructing, or acquiring the housing project) to enable them, without financial assistance, to live in decent, safe and sanitary dwellings, without overcrowding ....

Apparently only Virginia has a similar law, which provides that the selection of a low-income public housing site in a city with a population not greater than ninety thousand nor less than seventy thousand shall be subject to a city referendum unless the project is authorized for the purpose of relocating families displaced by urban renewal. VA. CODE \& 36-19.4 (1950). Alabama law provides that public housing projects may not be 
which requires a local housing authority's selections of low-income public housing sites to be approved in community referenda. ${ }^{5}$

In its opinion the Court touched upon three primary issues: (1) the nature of referenda provisions and the scope of judicial review over them; (2) almost parenthetically, the effect of the referendum upon the rights of an economic minority-the poor; and (3) the referendum's effect upon the rights of racial minorities. The Court broadly endorsed the referendum and implied that referenda should not be subjected to a stringent standard of judicial scrutiny. The Court found that the record would not support the lower court's finding that the provision, although neutral on its face, imposed increased procedural burdens upon racial minorities. ${ }^{\circ}$ Although it suggested that the referendum procedure might disadvantage some persons in the political process, the Court's majority never explicitly referred to the economic composition of that group which had been singled out for special treatmentlow-income persons who apply for public housing. The Court found,

alienated by the local governing body unless the decision is approved by referendum. ALA. CoDE tit. 47, $\$ 62(1)$ (1958). Wisconsin law provides that a project may be liquidated or disposed of by referendum. Wis. STAT. ANN. $\$ 66.40(25)$ (a) (1957).

5 The origins of article XXXIV can be briefly summarized:

The United States Housing Act of 1937 (42 U.S.C.A. \$\$ 1401-1430) established a federal housing agency authorized to make loans to state agencies for the purpose of slum clearance and low-rent housing projects. The California Legislature made the benefits of the federal act available to the cities and counties of this state by enacting the Housing Authorities Law ....

The legislation created in each city and county a public housing authority. ... The exercise of the powers entrusted by the Legislature to these agencies was made subject to the preliminary condition that the local governing body, in each case, must formally resolve that public housing is needed.

Housing Authority v. Superior Court, 35 Cal. 2d 550, 552-53, 219 P.2d 457, 458 (1950). In that case the California Supreme Court held that the determination of the housing authority as to site selection of projects was administrative, not legislative, and thus not subject to the general nonmandatory referendum provision. This decision was overruled by article XXXIV, which was adopted in the same year through initiative and referendum.

6402 U.S. at 141. The lower court opinion is Valtierra v. Housing Authority, 313 F. Supp. 1 (N.D. Cal. 1970). A curious difference in perspective between the two opinions is evident. The lower court opinion seems to indicate that the racial and poverty aspects of the case are inseparable, while the Supreme Court opinion summarily disposes of the racial aspect of the case and completely ignores the poverty issue. Justice Marshall's dissent, on the other hand, focuses on the statute's explicit classification on the basis of wealth but fails to mention the racial aspect of the case.

The term "race" as used herein includes minority groups other than blacks, including Mexican-Americans, Puerto Ricans, and Indians, all of whom suffer much the same type of discrimination as does the black man. See, e.g., U.S. Comm'N on Civit RIGHTS, MExicAN. AMERICAN Education STUDY 11 (1971): "The Southwest has had a long history of ethnic isolation and segregation of Mexican Americans from the remainder of its society. Although segregation probably never has been required by statute in any of the five Southwestern States, it has been practiced not only in the schools of the region, but in other aspects of life as well." 
however, that the community's interest in determining the level of local governmental expenditure and taxation outweighed whatever disadvantages might be incurred by others through the mandatory referendum procedure.

This comment will focus on the three constitutional issues posed by the Valtierra case: (1) whether the standard of judicial scrutiny of referendum legislation and decisions is or should be identical to that which applies to representative legislative enactments; (2) whether explicit classifications based upon wealth are or should be disfavored on new or substantive equal protection grounds; and (3) whether the California provision, although neutral on its face, may have an impermissible racially discriminatory effect-raising the question whether the Court's opinion in this respect is consistent with such decisions as Reitman v. Mulkey ${ }^{7}$ and Gautreaux v. Chicago Housing Authority. ${ }^{8}$

\section{JUdicial SCRUTINY OF REFERENDUM LEgisLation}

Initially, it is important to determine whether the presumed validity of challenged legislation is affected by the manner in which it is enacted-by the people themselves or by the people's representatives. ${ }^{9}$ The majority of the Valtierra Court appear to have believed that referendum legislation and decision making occupy a special place in the political process so as to merit a greater presumption of validity than that which attaches to representative legislation. The Court emphasized that the referendum is a "procedure for democratic decisionmaking" and that "provisions for referendums demonstrate devotion to democracy, not to bias, discrimination, or prejudice."10

As the following discussion shows, such a blanket endorsement is inconsistent not only with standards previously announced by the Court, but also with the fourteenth amendment's protection of minorities against unrestrained majority will. ${ }^{11}$

7387 U.S. 369 (1967).

8296 F. Supp. 907, 304 F. Supp. 736 (N.D. I11. 1969).

o In Housing Authority v. Superior Court, 35 Cal. 2d 550, 219 P.2d 457 (1950), the court held that the decision of the housing authority as to site selection was administrative, not legislative, and thus not subject to the existing referendum provision. The court stated that the California statute setting up local housing authorities "expressly recognizes the existence of slum and substandard living areas and enunciates the government's intent to eliminate them," id. at 553, 219 P.2d at 458, and, quoting Kleiber v. City and County of San Francisco, $18 \mathrm{Cal} .2 \mathrm{~d} 718,724,117$ P.2d 657, 660 (1941), that " the subject matter of the action is of more than local concern," $i d$. at 558, 219 P.2d at 461.

10402 U.S. at 141.

11 See Lucas v. Colorado General Assembly, 377 U.S. 713, 736-37 (1964). Other courts have gone so far as to enjoin the submission of certain proposals to public referenda 
Perhaps the Court's most instructive statement on referendum legislation came in Lucas v. Colorado General Assembly. ${ }^{12}$ Two amendments to the Colorado Constitution had been proposed by initiative. The first proposal provided for one-man, one-vote representation in both houses of the state legislature, while the second provided for one-man, one-vote representation in the more numerous house only. The second proposal was approved in a public referendum. Against claims that the measure violated the fourteenth amendment, the district court upheld its constitutionality, explaining that it was precluded from reversing the people's judgment rendered in accordance with Colorado's liberal provisions for citizen participation in the governmental process. ${ }^{13}$ Faced with the unusual situation of a majority of the electorate denying itself equal representation in both houses of the state legislature, the Supreme Court disapproved the plan, stating that a majority may not, through a public referendum, infringe upon a citizen's constitutional rights. ${ }^{14}$

Lucas, therefore, appears to stand for the principle that when the people act as a legislative body in a referendum, the Constitution imposes upon them the same responsibilities as it imposes upon a representative legislature, and that voter legislation, even if it does "demonstrate devotion to democracy,"15 or citizen majority rule, is not given any greater presumption of validity for that reason.

For the Valtierra Court to extol in unqualified fashion the virtues of the referendum was thus unnecessary and misleading. Moreover, apart from Lucas, it may have cast doubt upon a basic principle of Hunter v. Erickson"16 - that "a State may distribute legislative powers as it desires and that the people may retain for themselves the power over certain subjects may generally be true, but [that] these principles furnish no justification for a legislative structure which would otherwise violate the Fourteenth Amendment. Nor does the implementation of this change through popular referendum immunize it."17

because the effect of the submission itself was prohibited by the fourteenth amendment. In Holmes v. Leadbetter, 294 F. Supp. 991 (E.D. Mich. 1968), and Otey v. Common Council, 281 F. Supp. 264 (E.D. Wis. 1968), submission of open housing referendum proposals to the electorate was held to be within the "encouragement" prohibition of Reitman v. Mulkey, 387 U.S. 369 (1967). For a discussion of the Reitman decision, see text at notes 109-24 infra.

12377 U.S. 713 (1964).

13 Lisco v. Love, 219 F. Supp. 922, 932-33 (D. Colo. 1963), rev'd sub nom. Lucas v. Colorado General Assembly, 377 U.S. 713 (1964).

14377 U.S. at 736-37.

15402 U.S. at 141.

16393 U.S. 385 (1969).

17 Id. at 392. 


\section{Validity of Explicit Classifications Based upon Wealth}

Any discussion of the validity of classifications based upon wealth under the new or substantive equal protection doctrine is difficult and somewhat speculative in the context of Valtierra because the Court's opinion failed to address that question. Justice Black ignored not only the points raised by Justice Marshall in his dissent ${ }^{18}$ but also those cases in which the Court has stated that classifications based upon wealth, like those based upon race, are "suspect."10 In view of the exclusive applicability of the California referendum provision to lowincome housing projects, an examination of the Court's opinion in terms of both the new and the old equal protection doctrines appears to be warranted.

\section{A. Equal Protection-Old and New}

The old and new equal protection doctrines, the subject of wide debate and discussion in recent years, ${ }^{20}$ require only brief summarization. Under the old equal protection, legislative classifications are allowed a strong presumption of validity and are constitutionally permissible if "rationally related to a legitimate governmental objective."21 The contrast with the new equal protection is striking. In recent years the Court has indicated that the new equal protection encompasses two primary branches, fundamental rights ${ }^{22}$ and suspect criteria. While the suspect category was initially limited to racial criteria, ${ }^{23}$ the Court's recent decisions have suggested that classifica-

18402 U.S. at 145. Justice Marshall stated that "[i]t is far too late in the day to contend that the Fourteenth Amendment prohibits only racial discrimination; and to me, singling out the poor to bear a burden not placed on any other class of citizens tramples the values that the Fourteenth Amendment was designed to protect." Justices Brennan and Blackmun concurred in the dissent. Justice Douglas took no part in the case.

19 See e.g., McDonald v. Board of Election Comm'nrs, 394 U.S. 802, 807 (1969); Harper v. Virginia Bd. of Elections, 383 U.S. 663, 668 (1966); Douglas v. California, 372 U.S. 353, $355-58$ (1963).

20 See, e.g., Black, The Supreme Court, 1966 Term, Foreword: "State Action", Equal Protection and California's Proposition 14, 81 HARv. L. REv. 69, 96-99 (1967); Karst \& Horowitz, Reitman v. Mulkey: A Telophase of Substantive Equal Protection, 1967 SUP. CT. REv. 39; Michelman, The Supreme Court, 1968 Term, Foreword: On Protecting the Poor Through the Fourteenth Amendment, 83 FARv. L. REv. 7 (1969); Sager, Tight Little Islands: Exclusionary Zoning, Equal Protection and the Indigent, 21 STAN. L. REv. 767 (1969); Developments in the Law-Equal Protection, 82 HARv. L. REv. 1065 (1969).

21 Shapiro v. Thompson, 394 U.S. 618, 658 (1969) (Harlan, J., dissenting).

22 See Shapiro v. Thompson, 394 U.S. 618 (1969); Williams v. Rhodes, 393 U.S. 23 (1968); Carrington v. Rash, 380 U.S. 89 (1965); Reynolds v. Sims, 377 U.S. 533 (1964); Skinner v. Oklahoma, 316 U.S. 535 (1942).

23 See Loving v. Virginia, 388 U.S. 1 (1967); McLaughlin v. Florida, 379 U.S. 184 (1964); Korematsu v. United States, 323 U.S. 214 (1944). 
tions based upon wealth are also included. ${ }^{24}$ When either a suspect criterion has been incorporated into a statute or the exercise of a fundamental right is threatened, the statutory classification must be justified by a "compelling governmental interest." 25

Application of the new equal protection doctrine involves close "judicial scrutiny"26 imposing upon the state a heavy burden of justification. ${ }^{27}$ Concomitantly, the Court has sometimes considered whether there are alternatives available to the state by which it can achieve its legitimate objective without substantial infringement upon fundamental rights or without classification by means of suspect criteria. $^{28}$ If the Court finds a "less onerous alternative" by which a state is able to achieve its legitimate objective, the state may not employ a method which, though rationally related to that objective, more substantially infringes upon protected rights. ${ }^{29}$

\section{B. Wealth as a Suspect Criterion}

The majority in Valtierra, while noting that classifications based upon race are constitutionally suspect, ignored the Court's previous statements that classifications based upon wealth also fall within the suspect category: "Lines drawn on the basis of wealth, like those of

24 See cases cited note 19 supra. Justice Harlan's dissent in Shapiro v. Thompson, 394 U.S. 618,658 , succinctly summarized what he perceived to be the trend of the Court's decisions in this area:

In upholding the equal protection argument, the Court has applied an equal protection doctrine of relatively recent vintage: the rule that statutory classifications which either are based upon certain "suspect" criteria or affect "fundamental rights" will be held to deny equal protection unless justified by a "compelling" governmental interest. The "compelling interest" doctrine, which today is articulated more explicitly than ever before, constitutes an increasingly significant exception to the long-established rule that a statute does not deny equal protection if it is rationally related to a legitimate governmental objective.

Justice Harlan's earlier view of the Court's trend is quite different, as expressed in his dissent in Cardona v. Power, 384 U.S. 672, 660-61 (1966):

It is suggested that a different and broader equal protection standard applies where "fundamental liberties and rights are threatened,"... which would require a state to show a need greater than mere rational policy to justify classifications in this area. No such dual-Ievel test has ever been articulated by this Court, and I do not believe any such approach is consistent with ... the Equal Protection Clause . ... 25 Cf. Shapiro v. Thompson, 394 U.S. 618, 634 (1969). See also Sherbert v. Verner, 374 U.S. 398, 406 (1963); Bates v. Little Rock, 361 U.S. 516, 524 (1960); Korematsu v. United States, 323 U.S. 214, 216 (1944); Skinner v. Oklahoma, 316 U.S. 535, 541 (1942).

26 McDonald v. Board of Election Comm'rs, 394 U.S. 802, 807 (1969). For views regarding the content of the concept of "close judicial scrutiny," the point of departure for application of the new equal protection standard, see Karst \& Horowitz, supra note 20; Michelman, supra note 20; Sager, supra note 20.

27 See cases cited note 25 supra; Michelman, supra note 20, at 20.

28 See Tate v. Short, 91 S. Ct. 668 (1971); Anders v. California, 386 U.S. 738 (1967); Carrington v. Rash, 380 U.S. 89 (1965).

28 Cf. Carrington v. Rash, 380 U.S. 89 (1965). 
race ... are traditionally disfavored."30 "[C]areful examination on our part is especially warranted where lines are drawn on the basis of wealth or race, . . . two factors which would independently render a classification highly suspect and thereby demand a more exacting judicial scrutiny." 31

The cases in which the Court has invalidated statutes containing classifications based upon wealth have also involved barriers hindering the indigent in the exercise of certain fundamental rights, sometimes formulated for the first time in those cases. ${ }^{32}$ In such decisions the question whether wealth, as a suspect criterion, formed an independent basis for the determination of constitutional invalidity or was merely an ancillary consideration has never been expressly resolved. Justice Harlan indicated, however, that the criterion of wealth may have provided an independent basis for invalidation when he stated that "[t]he criterion of 'wealth' apparently was added to the list of 'suspects' as an alternative justification for the rationale in Harper v. Virginia Bd. of Elections ...."33 On the other hand, it has been forcefully argued that because fundamental rights of voting and access to the judicial process in criminal cases were involved, the finding of a suspect criterion was unnecessary to the decision. ${ }^{34}$ Inability to pay a fee had no reasonable relationship to a proper governmental objective and, in addition, a pecuniary burden on the exercise of those fundamental rights might have been invalidated under the due process clause.

\section{McDonald v. Board of Election Commissioners, ${ }^{35}$ however, has}

30 Harper v. Virginia Bd. of Elections, 383 U.S. 663, 668 (1966).

31 McDonald v. Board of Election Comm'rs, 394 U.S. 802, 807 (1969) (emphasis added). 32 See Boddie v. Connecticut, 401 U.S. 371 (1971) (access to court for divorce proceedings); Williams v. Illinois, 399 U.S. 235 (1970) (imprisonment for longer than maximum statutory sentence for nonpayment of fine); Roberts v. LaVallee, 389 U.S. 40 (1967) (transcript of preliminary hearing for use at trial); Anders v. California, 386 U.S. 738 (1967) (effective advocacy by court-appointed counsel); Douglas v. California, 372 U.S. 353 (1963) (counsel on first appeal from conviction); Smith v. Bennett, 365 U.S. 708 (1961) (filing fee for application for writ of habeas corpus); Burns v. Ohio, 360 U.S. 252 (1959) (filing fee for motion for leave to appeal); Griffin v. Illinois, 351 U.S. 12 (1956) (trial transcript for appeal).

33 Shapiro v. Thompson, 394 U.S. 618, 658-59 (1969) (dissenting opinion).

34 However, even one skeptical of the proposition that such cases make the poor a judicially favored class under the new equal protection admits that "[h]eightened judicial skepticism about statutes which explicitly isolate an economic class for special treatmenti.e., the cases 'where lines are drawn on the basis of wealth'-is . . obviously justified." Michelman, supra note 20, at 26-27.

35394 U.S. 802 (1969). The Court upheld the validity of an absentee ballot statute which had the effect of preventing inmates awaiting trial in Cook County Jail who were residents of Cook County from obtaining absentee ballots while inmates who were residents of other counties could do so. 
drawn into question this restrictive explanation of the cases involving the poor. Presented with an equal protection challenge to a state absentee ballot procedure, the Court deferred its discussion of the merits of the case until it determined "how stringent a standard to use in evaluating the classifications made [by the statute] and whether the distinctions must be justified by a compelling state interest." 36 The Court stated that the exacting standards of the new equal protection would be applied if the statute involved a classification "drawn on the basis of wealth or race." 37

The analytical approach of $M c D o n a l d$, under which the standard for testing the classification is determined before the substantive issues in the case are decided, was not followed in Valtierra, which the Court decided without specifying which equal protection standard it was applying. The Court thus avoided the question whether a classification based upon wealth, like a racial classification, provides an independent basis for application of the new equal protection. Until Valtierra, as noted, the cases afforded sound reason to believe that classifications based upon wealth are within the suspect category. These precedents were emphasized in Justice Marshall's dissenting opinion, but the Court failed to respond to them. Through its silence, the Court obscured the developing clarification of a constitutional principle and thereby invited conflicting lower court interpretations. ${ }^{38}$

Assimilation of a prohibition of classifications based upon wealth to the prohibition of racial classifications cannot be accomplished in an unquestioned fashion, notwithstanding one court's succinct rationale for constructing an analogy between the two criteria. In Hobson $v$. Hansen $^{39}$ Judge Wright explained that although the judiciary usually defers to administrative and legislative resolutions of conflicting interests, its faith in the justice of such resolutions is often misplaced when the interests of the poor or racial minority groups are involved. A closer judicial scrutiny of judgments adverse to the interests of these groups is necessary because they "are not always assured of a full and fair hearing through the ordinary political processes, not so much because of outright bias, but because of the abiding danger that the power structure . . . may incline to pay little heed to even

36 Id. at 806.

37 Id. at 807.

38 The confusion to which the Valtierra Court has exposed lower courts was apparent in the recent decision of Serrano v. Priest, - Cal. 3d -, 487 P.2d 1241, 96 Cal. Rptr. 601 (1971). There the California Supreme Court held the state school-financing scheme unconstitutional on equal protection grounds.

39269 F. Supp. 401,507 (D.D.C. 1967). 
the deserving interests of a politically voiceless and invisible minority." 40 There are major obstacles, however, to the assimilation of wealth to race as a suspect criterion: the positive value society places upon distinctions of wealth, the tradition of state-imposed financial prerequisites for the enjoyment of certain services and activities, the belief that poverty is remediable, the difficulty of determining what constitutes poverty, and, finally, the difficulty of defining the limits on the substantive areas to which the new equal protection should apply.11

Despite these obstacles, there are reasons why the poor, like racial minorities, should be afforded special judicial treatment under the new equal protection. The poor are increasingly comprised of particular racial and ethnic minority groups, ${ }^{42}$ so that economic discrimination may be merely a guise for racial discrimination. ${ }^{43}$ Moreover,

40 Id. at $507-08$.

41 See Sager, supra note 20, at 785-87. As Professor Sager notes, race is not a valid consideration in determining access to housing, employment opportunities, and places of public accomodation and amusement. It is a far different matter to suggest, however, that wealth should not be a determinative factor. No man is entitled to a twenty thousand dollar home; to a higher salary; or to free admission to hotels, restaurants, and theaters because he is poor. The state charges all persons equally for use of toll roads and universities; for fishing, hunting, and driver's licenses; and more. Because wealth, in contrast to race, is a relative factor, the income level at which a person is entitled to state-provided services is largely discretionary, although qualifying standards which are particularly arbitrary may be effectively challenged. Finally, because poverty, unlike race, is considered remediable, one might be less concerned with the adverse effects of distinctions drawn on the basis of wealth.

42313 F. Supp. at 5.

In 1967, 41 percent of the nonwhite population was poor, compared with 12 percent of the white population. Nonwhites thus constitute a far larger share of the poverty population (31 percent) than of the American population as a whole (12 percent). Moreover, the nonwhite proportion of the poverty population has been increasing slowly but steadily, since the first racial count was made in 1959; it was 28 percent then, and 32 percent by 1967.

National Comm'n on Urban Problems, Building the american City, H.R. Doc. No. 9I34, 91st Cong., Ist Sess. 45 (1968).

43 See Fiss, $A$ Theory of Fair Employment Laws, 38 U. CHI. L. REv. 235, 296 (1970); text at notes 95-96 infra. In his discussion of the theory of functional equivalence, Professor Fiss states:

The question then is whether the reach of the antidiscrimination prohibition has been exhausted, and three factors may justify a second look at the criterion: evasion, unfair treatment, and the impact of the criterion on the equal-achievement goal.

The first factor-evasion-[is rooted in a concern that a person will try] . . . to satisfy his taste for discrimination ... by using a criterion which does not mention race but which accomplishes precisely the same result ....

Second, an attempt to reach the seemingly innocent criterion may be rooted in a concern for fair treatment of Negroes. It is thought just as unfair to judge a Negro on the basis of such a criterion as it is to judge him on the basis of race ..... Of course, it may be unfair to judge anyone, white or black, on the basis of such a criterion; but this does not lessen the unfairness when Negroes are judged by such a criterion ....

A third source of concern relates to the goal of improving the relative economic positions of blacks. 
it is superficial to assume that poverty is easily overcome-particularly by members of racial minority groups, for whom residential segregation is a substantial hindrance. And as affluent Americans migrate to the suburbs, the poor-particularly those of racial minority groups -increasingly inhabit decaying urban centers. ${ }^{44}$ The consequent decline in tax receipts in urban areas causes a corresponding decline in the quality of municipal services-particularly education, an important prerequisite to employment. The isolation of the poor is exacerbated by the reduction of employment opportunities caused by the flow to the suburbs of commercial and industrial facilities, ${ }^{45}$ a phenomenon which further decreases urban tax receipts and aids in perpetuating a cycle of poverty. While this trend might be counteracted by locating low-income housing in areas of growing employment opportunities and better educational facilities, the referendum provision in Valtierra permits wealthy suburban escapees to veto lowincome housing on the apparent grounds of minimizing municipal expenditures and taxation. If such housing is to be built at all, it must apparently be located in the decaying central cities. ${ }^{46}$

\section{Application of the Suspect Criterion of Wealth}

Article XXXIV of the California Constitution makes an explicit, de jure classification based upon wealth; ${ }^{47}$ for, as Justice Marshall pointed out, "[p]ublicly assisted housing developments designed to accommodate the aged, veterans, state employees, persons of moderate income, or any class of citizens other than the poor, need not be approved by prior referenda." 48 Although the Valtierra Court did not

14 See Sloane, Toward Open Adequate Housing: The 1968 Housing Act: Best Yet-But Is It Enough?, 1 Crv. Richrs Dig., No. 3, at 1, 4-5 (1968).

45 The fact is that an ever-increasing number of industrial concerns and businesses are locating plants in suburban areas. The Bureau of Labor Statistics has reported that for the period 1960-1967, sixty-two per cent of all industrial buildings and fifty-two per cent of all commercial buildings were constructed outside the central cities of metropolitan areas. Moreover, more than fifty per cent of all new jobs created in the 1960's in the standard metropolitan areas were outside the central city.

Note, Snob Zoning: Must a Man's Home Be a Castle?, 69 Mich. L. REv. 339, 340 (1970), citing Bureau of Labor Statistics, U.S. Dep't of Labor, Changes in Urban America 1-5 (BLS Rep. No. 353, 1969).

46 The U.S. Commission on Civil Rights found last year that of the quarter of a million low-rent housing units that have been built by city public housing authorities in the Nation's 24 largest metropolitan areas, in only one-Cincinnati-has the city housing authority been permitted to build outside the central city. There, the authority has provided a total of 76 low-rent units in a Negro enclave in the suburbs. Sloane, supra note 44 , at 3 .

47 Most commentators have limited their discussions of the "classifications based upon wealth" standard to de facto classifications, apparently assuming that a de jure classification would be invalid. See, e.g., Michelman, supra note 20; Sager, supra note 20.

48402 U.S. at 144 (Marshall, J., dissenting). 
state clearly what standard it applied in determining the validity of article XXXIV, it is instructive to analyze the case first in terms of the new equal protection standard.

Assuming wealth is a suspect criterion, the California referendum could have been upheld only were the state able to demonstrate a compelling interest to justify the provision. In its best light, the referendum may be characterized as a measure directed primarily at minimization of municipal expenditures and taxation. The Supreme Court has held, however, that a state interest in saving money is not compelling when it infringes upon the exercise of fundamental rights. In Shapiro v. Thompson ${ }^{40}$ the Court invalidated a one-year residence requirement for welfare benefits eligibility because it created an "invidious classification" in violation of the equal protection clause, infringing upon the fundamental right to travel interstate. The state attempted to justify the statutory classifications on the grounds that the residence requirement was "a protective device to preserve the fiscal integrity of state public assistance programs" and "an attempt to distinguish between new and old residents on the basis of the contribution they have made to the community through the payment of taxes." "שo The Court firmly rejected both arguments, finding that such "reasoning would logically permit the State to bar new residents from schools, parks, and libraries, or deprive them of police and fire protection" and "would permit the State to apportion all benefits according to the past tax contributions of its citizens." 51 Although the Court recognized the legitimacy of a state purpose to limit expenditures and taxation, the method chosen was void because "saving of welfare costs cannot justify an otherwise invidious classification."52

The arguments of the Valtierra appellants are barely distinguishable from those of the Shapiro appellants-that indigents should be barred from residing in a particular area because their contributions to its tax base would be insufficient to cover the additional governmental expenditures entailed by such residence. Since a municipality is a branch of the state, it reasonably follows that saving money is not a compelling interest even when a community relies upon it to justify barring indigents from residing therein in public housing. ${ }^{53}$ And if

40394 U.S. 618 (1969).

50 Id. at 627,632 .

51 Id. at 632-33.

52 Id. at 633 .

53 In a different context, a lower federal court has held that municipal services must be apportioned equally among members of the community. In Hawkins v. Town of Shaw, $437 \mathrm{~F} .2 \mathrm{~d} 1286$ (5th Cir. 1971), the plaintiffs alleged racial discrimination in the apportionment of municipal benefits and services. Although the court found no evidence that local 
such an interest is not compelling under the fundamental right branch of the new equal protection, it is doubtful that it is compelling under the suspect criterion branch.

Moreover, had the "Iess onerous alternative" doctrine been considered in Valtierra, the Court may have found that other methods exist whereby California could achieve its objective of minimizing financial hardships incurred by particular communities through the location of low-income public housing sites. The state legislature could, for example, distribute the present burden on local finances by providing communities that have public housing with state grants equal to the difference between the amount the community would have received through taxation of the project at full value and the amount received under existing statutes, which appropriate ten percent of the project's rental monies to the community.

\section{Application of the Old Equal Protection Standard}

The remaining question is whether article XXXIV is valid under the old equal protection standard-whether the classification made is "rationally related to a legitimate governmental objective."54

First, the purpose of article XXXIV must be shown to be permissible. In Valtierra, there is a question as to what the purpose is. While providing local communities with a determinative voice in government spending appears to be a permissible purpose, barring indigents unable to assume their proportionate share of the tax burden appears to be impermissible in the light of Shapiro. ${ }^{55}$ Second, even if it is assumed that cost minimization is the purpose underlying article XXXIV, the mandatory referendum provision may still not satisfy the rational relation test because the category singled out for prior approval may be underinclusive. As the Supreme Court has indicated, the line between rational and irrational is fine. In Rinaldi v. Yeager ${ }^{56}$ the Court invalidated a state requirement that an unsuccessful appellant repay the cost of a state-provided transcript. The statute, which applied only to guilty defendants incarcerated after appeal but not to

officials had been racially motivated in the distribution of these services, the fact that nearly all municipal improvements had been made in the wealthier, white sections of town to the neglect of the poorer, black sections was sufficient to bring the conduct within the prohibition of the equal protection clause.

54394 U.S. at 658. (Harlan, J., dissenting).

55 394 U.S. at 633. In concluding its analysis of the state's fiscal integrity argument, the Court said that "neither deterrence of indigents from migrating to the State nor limitation of welfare benefits to those regarded as contributing to the State is a constitutionally permissible state objective."

.68 384 US. 305 (1966). 
those receiving suspended sentences or probation, was held to constitute an invidious discrimination in violation of the equal protection clause. While the purpose of the statute was to reimburse the state, the Court stated that the equal protection clause "require[s] that, in defining a class subject to legislation, the distinctions that are drawn have 'some relevance to the purpose for which the classification is made." "57 Apparently determining that the statutory classification was underinclusive, the Court found that "no defensible interest [was] served by focusing on that distinction as a classifying feature in a reimbursement statute, since it bears no relationship whatever to the purpose of the repayment provision." 58

Whether the classification in article XXXIV is more relevant to the purpose of the statute than the classification struck down in Rinaldi is arguable. The determination of rationality appears to involve two considerations directed to the question of underinclusiveness: the extraordinary character of mandatory referenda and the subject matter of the statute-in this instance, low-income public housing. Despite California's long history of referenda, ${ }^{59}$ few subjects have been deemed sufficiently important to require mandatory referenda. Furthermore, no other mandatory referendum provision has singled out a particular economic group to bear its burden. ${ }^{60}$ Whether the Rinaldi standard requires a determination of irrationality seems to depend upon whether municipal expenditures would have to be increased without commensurate increase of tax revenues from other types of housing developments for which referenda are not required. ${ }^{61}$ Thus, if com-

67 Id. at 309.

88 Id.

59402 U.S. at 141. In its discourse about the democratic referendum procedure, the Court added one puzzling suggestion. It implied that the validity of the challenged referendum provision was attributable, in part, to California's long history of referenda. As a constitutional principle this cannot withstand analysis. Should an identical constitutional amendment be enacted in another state lacking California's history of referenda, the absence of previous provisions of a similar nature should not be viewed as grounds for constitutional invalidity. Redress from infringement of important constitutional rights should not turn on such historical accidents.

60 The Court in Valtierra mentioned four types of referenda. State constitutional amendments are permissible since the constitution is adopted by the voters initially and any changes in it should be subject to their approval. Municipal bond referenda are, under Shapiro, a permissible method of adjusting the level of municipal expenditures as long as the benefit or hardship is evenly distributed. Territorial annexations permit selfdetermination by persons residing in an area sought to be annexed by a neighboring municipality. And legislation first enacted by voter initiative, unless repealable only by referendum, would be subject to repeal by the state legislature immediately after enactment. The subject matter of each of these provisions, however, is clearly different from that of article XXXIV.

61 It should be noted that some low-income public housing is not subject to referenda. 
munities permit the construction of other types of housing, or perhaps of other types of land use, which are either exempt from local taxation or which do not make a fair contribution to the tax base, the Rinaldi test of rationality may not be met.

Perhaps, as Justice Black warned in the majority opinion, to invalidate article XXXIV would presumably mean that a community could not adopt a referendum procedure on any subject unless it submitted all subjects to referenda. ${ }^{62}$ Valtierra can be distinguished, however, since the provision challenged in that case singles out a particular economic group which alone has to bear the special procedural burden of a referendum. Of course, it is possible that the referendum provision is not arbitrary because it may reflect a careful determination by the community that the benefits provided by other kinds of tax-exempt land uses and housing uniformly outweigh any additional costs imposed, ${ }^{63}$ but no such calculation was demonstrated by the state.

Nevertheless, certain policy considerations may lend support to the Court's decision in Valtierra. The construction of low-income public housing compels the community to subsidize the project through the

The referendum procedure is required only for housing units owned by the local housing authority, not for units leased from private landlords nor for certain types of replacement units for persons displaced by a highway project. 51 Op. CAL. ATr'Y GEN. 245 (1968); id. at 42; see Note, Racial Discrimination in Public Housing Site Selection, 23 STAN. L. REv. $63,66(1970)$. In addition, the program authorized by section 23 of the Housing and Urban Development Act of 1965, 42 U.S.C. \& 1421b(f) (1970), "does not constitute . . . a "low-rent housing project,' as that term is used in article XXXIV of the State Constitution," so that no prior approval at an election is required. 47 Or. CAL. ATT'y GEN. 17, 18 (1966). It would seem that under section 23, units rented from private landlords by the local housing authority are not tax-exempt as are publicly owned housing projects under 42 U.S.C. $\S 1410(\mathrm{~h})(1970)$.

Moreover, in California a variety of land uses are exempt from local taxation but are not subject to referenda. See, e.g., CAL. Const. art. XIII, § 1; CAL. REv. \&. TAX. CodE § 202 (public libraries and free museums); CAL. Const. art. XIII, § 1(a); CAL. REv. \& TAX. CODE §§ 202-03 (Deering 1958) (colleges, including college housing, and public schools); CAL. CoNST. art. XIII, § 1(c); CAL. REv. \& TAX. CODE § 214 (Deering 1958) (property used exclusively for religious, scientific, hospital, or charitable purposes); CAL. CoNSr. art. XIII, § 11/2; CAL. REv. \& TAX. CoDE §§ 206, 206.1 (Deering 1958) (church property); CAL. Const. art. XIII, § 123/4; CAL. REv. \& TAX. CODE $\$ 211$ (Deering 1958) (land used for young grape vines and fruit- and nut-bearing trees). Many of the foregoing land uses directly impose additional costs upon the community, and all indirectly impose such costs by removal of land from possible uses, such as factories, from which localities could reap high property tax revenues.

62402 U.S. at 142.

6342 U.S.C. $\$ 1410(\mathrm{~h})(1970)$. The public housing authority does give the local community in which a project is located ten percent of its rentals. In addition, the authority must pay for any "municipal services" performed by private parties for which other members of the community must pay a fee. Jersey City Sewerage Authority v. Housing Authority, 40 N.J. 145, 190 A.2d 870 (1963). 
imposition of higher taxes or by a decline in the level of municipal services. Although public housing projects can significantly dilute the tax base, Shapiro indicates that apportionment of municipal services in accordance with individual contribution is impermissible. However, because the community's residents must bear an extra financial burden, it may seem only fair to allow them to have an influence in determining whether or not to undertake that burden.

\section{Determination of an Implicit Racial Classification}

From the time it was determined both judicially and legislatively that race was an impermissible criterion in the wholly private housing market, ${ }^{64}$ the question of illegal racial discrimination in housing has become more subtle. The present concern is that exclusion of blacks from white residential areas may be accomplished "by using a criterion which does not mention race but which accomplishes precisely the same result ...."65

The Valtierra Court, in addressing itself to the question whether an implicit racial classification is contained within the "benign" criterion of wealth in article XXXIV, found that "the record here would not support any claim that a law seemingly neutral on its face is in fact aimed at a racial minority,"06 citing Gomillion v. Lightfoot. ${ }^{67}$ This finding merits closer consideration.

\section{A. Motive or Effect}

If a statute is "neutral on its face," 88 the question immediately arises how a court should determine whether the "seemingly innocent criterion"60 or an impermissible criterion is the real basis of a statutory classification. There are two ways in which a court can make this determination-by focusing on the motives of the persons who made the decision or by focusing on the effect of the decision.

64 Jones v. Mayer Co., 392 U.S. 409 (1968), construing 42 U.S.C. § 1982 (1970), 42 U.S.C. §§ 3601-31 (Supp. V, 1969). The state was earlier forbidden to use race as a criterion in regulating the housing market. See, e.g., Hurd v. Hodge, 334 U.S. 24 (1948); Shelley v. Kraemer, 334 U.S. 1 (1948); City of Richmond v. Deans, 281 U.S. 704 (1930); Harmon v. Tyler, 273 U.S. 668 (1926); Buchanan v. Warley, 245 U.S. 60 (1917). This is not to suggest that the question in Valtierra is one of private discrimination, but rather that the difficulty of detecting discrimination in Valtierra is similar.

65 Fiss, supra note 43 , at 296.

68402 U.S. at 141.

o7 364 U.S. 339 (1960).

08402 U.S. at 141.

69 Fiss, The Charlotte-Mecklenberg Case-Its Significance for Northern School Desegregation, 38 U. CHI. L. REv. 697 (1971). 
In Valtierra, the Court's use of the phrase "aimed at"70 suggests that it was concerned not with any racially discriminatory effect which article XXXIV might have but rather with the motives of the voters in enacting the referendum provision. This suggestion is fortified by the Court's statement that "[p]rovisions for referendums demonstrate devotion to democracy, not to bias, discrimination, or prejudice."71 This emphasis on the virtues of referenda raises questions regarding the propriety and wisdom of a motive test, particularly in the context of community approval of proposed public housing sites.

Among the members of the Court and its critics, there are adherents of the motive test as well as of the effect test. ${ }^{72}$ Yet when the Court has been directly confronted with the motive-or-effect distinction in the determination of the constitutional validity of statutes, the majority of its members have opted for the effect test. Thus, in United States $v$. $O^{\prime} B^{\prime} r_{i e n}{ }^{73}$ the Court rejected motive as a possible basis of statutory invalidity and interpreted Gomillion as standing "not for the proposition that legislative motive is a proper basis for declaring a statute unconstitutional, but that the inevitable effect of a statute on its face may render it unconstitutional. ... [T] he purpose of the legislation was irrelevant, because the inevitable effect-the 'necessary scope and operation' . . - -abridged constitutional rights." 74 And in Norris $v$. Alabama ${ }^{75}$ the Court inferred from jury selection data that a racial criterion had been used in the selection procedure. The good motives and good faith to which the administrators testified apparently made no difference. Finally, in Palmer $v$. Thompson, ${ }^{76}$ decided shortly after Valtierra, the Court again confronted the motive-or-effect distinction. It upheld a city council's decision to close all segregated

70402 U.S. at 141.

$71 \mathrm{Id}$.

72 In Palmer v. Thompson, 403 U.S. 217 (1971), the most recent case in which the Court confronted the issue whether motive or effect is the proper test for determining racial discrimination, Chief Justice Burger and Justices Black, Blackmun, Douglas, Harlan, and Stewart favored the effect test while Justices White, Brennan, and Marshall preferred the motive test. For views of other commentators, see notes 43,69 supra and note 83 infra.

73391 U.S. 367 (1968).

$74 \mathrm{I} d$. at $384-85$.

75294 U.S. 587 (1935). The Court's approach in Norris should be contrasted with that in Yick Wo v. Hopkins, 118 U.S. 356 (1886), in which the Court did not infer from the data presented merely that the basis of classification in the statute's administration was race. Rather, the Court also inferred a motive of racial animus. Although under the particular circumstances of that case the inference may not have been mere speculation, it would have been equally consistent with the effect of the state's actions had the motive been a desire to assist white laundry operators rather than racial animus.

76403 U.S. 217 (1971). 
swimming pools after a federal district court had found that segregated municipal facilities constituted a denial of equal protection. In seeking to have the pools reopened on an integrated basis, the plaintiffs charged that the council's decision to close the pools rather than to integrate them had been motivated by racial animosity. While acknowledging that evidence supported the charge, the Court stated that "no case in this Court has held that a legislative act may violate equal protection solely because of the motivations of the men who voted for it." ${ }^{37}$ The Court admitted that language in some of its opinions ${ }^{78}$ suggests that motive is a relevant consideration in the determination of constitutionality but added that "the focus in those cases was on the actual effect of the enactments, not upon the motivation which led the States to behave as they did."'79

Both the O'Brien and Palmer decisions articulated several reasons for preferring the effect test to the motive test. A judicial determination of motive or a collection of motives would be a difficult, if not impossible, task. Moreover, if the Court did find an impermissible motive and voided a statute on that basis, it would be a Pyrrhic victory because the statute "would presumably be valid as soon as the legislature or relevant governing body repassed it for different reasons."80 Finally, it would be dysfunctional to void a statute which had a legitimate result simply because of the bad motives of those who enacted it. To these considerations can be added the fact that the legal system is usually concerned about racial discrimination only "when it appears that the alleged wrong has actually disadvantaged blacks, not when the complaint consists merely of an awareness that someone is thinking bad thoughts about blacks. That is, "[a]ntidiscrimination prohibitions try to regulate by prohibiting the use of a criterion (race), and generally a violation of the prohibition does not turn on the motives or reason for the choice of the criterion." 11

The preference for the effect test has not gone unchallenged. Justice White, in his dissent in Palmer, argued that the swimming pools should be reopened on an integrated basis because their closing had been racially motivated. ${ }^{82}$ The view that motive may be a valid con-

77 Id. at 224.

78 The Court mentioned Griffin v. County School Board, 377 U.S. 218 (1964), and Gomillion v. Lightfoot, 364 U.S. 339, $347^{\circ}(1960)$.

79403 U.S. at 225.

$80 \mathrm{Id}$.

81 Fiss, supra note 43, at 298.

82 In the O'Brien decision, however, both Justices Brennan and White joined in the Court's holding that effect, not motive, was the proper test. Justice Marshall did not take part in that decision. 
sideration has received support from other critics as well. ${ }^{83}$ It has been forcefully argued that the usual guidelines for the determination of constitutional validity are inadequate in certain situations. According to this theory, in certain "discretionary" legislative decisions, notably spending and taxing, a plaintiff alleging racial discrimination must show that he was disadvantaged by the statutory classification and that the decision makers were racially motivated in order to shift the burden of persuasion to the state..$^{84}$

Although it is conceded that a disproportionate racial effect may be the best evidence of motivation, it is not the effect but the inference of motivation which is crucial-this is because the state has no affirmative duty to help blacks but only a duty to be neutral. To discern motivation, it has been suggested that the court might examine four factors: "the terms of the law in issue, those effects which must have been foreseen by the decision makers, the historical context in which the law was passed, and the legislative history and other recorded statements of intention." 85 If the court became convinced of the presence of an impermissible motivation-racial animus, indicating that race was the criterion of selection-the burden would fall upon the state to justify the distinction. If the court detected the presence of other permissible motivations, the impermissible motivation would be controlling. The sole exception to this rule would operate when the court could find that only a minority of the decision makers were motivated by an impermissible criterion. ${ }^{86}$

The application of such a motive test to community referenda on low-income housing site selection in California might prove difficult. Within the Valtierra context, for example, the four suggested factors would not have been especially helpful to the plaintiff. First, the terms of article XXXIV are neutral with respect to race. Second, it would have been difficult for a court to make a reasonable decision about what possible racial effect California voters could have foreseen in enacting article XXXIV in 1950. Third, the provision was enacted in response to a state court ruling that California's general, optional referendum law was not applicable to selections of low-income public housing sites. Fourth, public statements made at the time of passage of article XXXIV do not indicate that racial bias played a role in its

83 E.g., Ely, Legislative and Administrative Motivation in Constitutional Law, 79 YALE L.J. 1205 (1970).

84 When the new equal protection standard is applicable, the state must demonstrate a compelling governmental interest to justify the distinction made.

85 Ely, supra note 83, at 1220.

86 Id. at 1268. 
enactment. ${ }^{87}$ Under the proposed motive test, regardless of the results of the referenda, the provision could not have been found unconstitutional.

The proponent of the motive test does, however, suggest one additional factor-the court can look at the impact of the provision, but only for the purpose of determining the permissibility of the motivation. Assume that the result is an intolerable one-low-income public housing is ninety percent black and every site proposed for a white residential area is vetoed while every site proposed for a black one is approved. ${ }^{88}$ Assume further that statistics show that a majority of white voters approved sites in black areas but disfavored sites in white ones. Before it could possibly make a finding of invalidity, the court must have found that the white voters, or at least a majority of them, were motivated by racial animus. Within the context of the hypothetical, an inference of racial animus would, judged in the light of extensive research by social scientists, be speculative at best. ${ }^{89}$

87 It is apparent from the appellants' and the appellees' briefs that California voters were concerned primarily about imposition by the federal government of costs upon particular localities without the consent of their residents. One pamphlet supporting the passage of article XXXIV stated:

Time after time within the past year, California communities have had public housing projects forced upon them without regard either to the wishes of the citizens or community needs. This is a particularly critical matter in view of the fact that the long-term, multimillion-dollar public housing contracts call for tax waivers and other forms of local assistance, which the Federal Government says will amount to half the cost of the federal subsidy on the project as long as it exists.

For government to coerce such additional hidden expense on the voters at a time when taxation and the cost of living have reached an extreme high is a "gift" of debatable value. It should be accepted or rejected by ballot ....

... [A] "yes" vote for this proposed amendment will strengthen local selfgovernment and restore to the community the right to determine its own future course.

Brief for Appellees at 14-15.

88 This hypothetical is based upon the facts found by the district court in Gautreaux v. Chicago Housing Authority, 296 F. Supp. 907, 304 F. Supp. 736 (N.D. Ill. 1969), discussed in text at notes $106-08$ infra.

89 See A. Camprell, P. Converse, W. Miller, \& D. Stokes, The American Voter (1960); A. Campbell, P. Converse, W. Miller, \& D. Stokes, Elections and the Political Order (1966). In the latter work the authors state: "Typically the line of explication has been 'downward' from the readily visible collective event to the component acts of individuals. As we have observed, this has led to speculative descriptions of the psychological basis of individual behavior, of which many have remained wholly untested and some have been proved by historical events to be untenable." $I d$. at 5 . The authors explain further that "[the] problem is to identify what this motivation is. ... [A]s long as one has only aggregative data at hand one can only speculate as to what moved the individual members of the collectivity ...."Id. at 2 .

While the results and conclusions of survey research analysis presently available can reliably aid the court in determining motivation, it is doubtful whether the court would choose to rely on survey research analysis. Courts have not previously measured motivation in this manner and might be reluctant to initiate a precedent of scientific probing 
A second problem arising from adoption of a motive test would be the determination of the percentage of impermissibly motivated decision makers required in order for a court to invalidate a measure. It has been suggested that a majority of voters must have had an impermissible motivation. ${ }^{90}$ In the hypothetical which has been posed, assume that survey research analysis indicates that thirty percent of the white voters voted against all proposed sites because they feared higher taxes, that thirty percent of the white voters voted against proposed sites in white neighborhoods because they do not like blacks, and that forty percent of the white voters approved all proposed sites because they feel sorry for the poor living in substandard housing. The result is that blacks are completely excluded from white residential neighborhoods. Yet only a minority of voters, albeit a crucial minority, were motivated by racial animus. ${ }^{91}$ Thus, the law would be valid under the proposed motive test.

One might argue, however, that it is the crucial racially motivated minority which should be determinative of invalidity-that if the votes of this minority were necessary to the outcome of the referendum, as they were in the hypothetical, the referendum provision should be held invalid; but that if a plurality of the voters would have disapproved the sites after excluding the racially motivated votes, the referendum provision should be upheld. While this standard might seem appealing on first impression, it is subject to the criticisms of ascertainability, futility, and disutility. ${ }^{22}$ Furthermore, courts may fear, with some justification, that a willingness to make an inquiry into voter motivations in the referendum context by scientific techniques might compel them to receive such evidence when representative legislation and administrative decisions are challenged as the products of illicit motives.

For several reasons, therefore, the effect test seems to be preferable, at least in the context of public housing referenda. If it is discriminatory effect which should be controlling, the crucial determination to have been made in Valtierra was not whether California voters

into people's minds upon every charge of racial discrimination. Furthermore, it is doubtful whether members of Congress or a state legislature would submit to such an examination of their motives. To limit scientific testing of motives to laws passed by the people themselves would perhaps be artificial if it is the surest way to obtain accuracy.

$90 \mathrm{Ely}$, supra note 83, at 1268.

91 Professor Ely, while preferring the motive test in racial discrimination cases, does not refer in his discussion of Reitman to survey research analysis which concluded that racial prejudice played a significant part in the passage of Proposition 14. Wolfinger \& Greenstein, The Repeal of Fair Housing in California: An Analysis of Referendum Voting, 62 AM. Por. Scr. Rev. 753 (1968).

-92 See text at notes 79-81 supra. 
were motivated by racial animus in approving article XXXIV in 1950 or in rejecting and approving housing sites since that time, but whether the provision has actually had a discriminatory effect. To say simply that there is no racial discrimination in article XXXIV because approval is required for all low-income public housing sites, not just for those in which blacks will live, does not answer the question whether the provision, although "neutral on its face," effect.

\section{B. Facially Innocent Criteria}

A statute is "neutral on its face" if it makes no express classification on the basis of an impermissible criterion such as race. It is "fair on its face and impartial in appearance." ${ }^{44}$ The concern is the "real' basis of the [classification]"-is it the "facially innocent criterion" it seems to be, or is it an impermissible criterion? ${ }^{95}$ To determine validity, the court must go beyond the face of the statute, examine its effect, and decide whether or not the "facially innocent criterion" is merely the "functional equivalent" ${ }^{\text {"B }}$ of an impermissible criterion.

In the Gomillion decision, for example, the Court invalidated a redistricting statute whose effect was that of "fencing Negro citizens out of town." 97 Residence was the facially innocent criterion which was found to be the functional equivalent of race, the real basis of a statute's classification.

In the context of public housing site selection, the question is whether low income is the functional equivalent of race-whether passing judgment on public housing on the basis of low income is the approximate equivalent of passing judgment on the basis of race. It has been suggested that there are two steps necessary to establish functional equivalence: "a determination that the criterion, like race, has or is likely to have an adverse differential impact on Negroes" and a determination that the criterion is no more justifiable as a basis of classification than is race..$^{98}$

The district court in Valtierra made both of these determinations, resting its conclusion upon the theory that low-income public housing is a functional equivalent of minority group housing. Not only did the district court find that the criterion had an adverse differential impact

\footnotetext{
93402 U.S. at 141.

94118 U.S. at 373.

95 Fiss, supra note 48, at 297.

96 Id. at 299.

97364 U.S. at 341.

98 Fiss, supra note 43 , at 299.
} 
upon racial minorities, ${ }^{99}$ but it also found that wealth was not a permissible basis of classification. ${ }^{100}$ The two criteria of wealth and race seem inseparable in the Court's opinion.

Although the Supreme Court hinted that article XXXIV might disadvantage some persons, it failed to give more than token acknowledgment to the existence of the wealth criterion on which the provision is based. Thus, it would have been difficult for it to have made a finding of functional equivalence. In the context of low-income public housing site selection, however, a court may not be required to make a determination that the criterion of wealth is no more justifiable than race in order to find that the two criteria are functionally equivalent. ${ }^{101}$ This determination of functional equivalence may depend upon two factors. First, it may be found to exist when the number or proportion of racial minority group members living in low-income public housing or on waiting lists reaches such a level that, as a practical matter, lowincome public housing becomes minority group housing. It is difficult to set a level of minority occupancy which should trigger the conclusion that low-income housing is minority housing. ${ }^{102}$ The Supreme Court did suggest a standard in Valtierra, however, when it stated that " $[t]$ he Article requires referendum approval for any low-rent public housing project, not only for projects which will be occupied by a racial minority."103 But if all or nearly all low-income housing projects are occupied, at least in part, by members of racial minority groups, the prohibited result may have been accomplished, whether intentionally or not, "by using a criterion which does not mention race but which accomplishes precisely the same result . . . ."104

This standard may, however, be too facile-something more may be necessary to make a determination of functional equivalence. The court

99 "[T] he impact of the law falls on minorities." $313 \mathrm{~F}$. Supp. at 5.

100 "It is no longer a permissible legislative objective to contain or exclude persons simply because they are poor." Id. at 4 .

101 In Gomillion the Court found that residence is a permissible redistricting criterion. Removal of the necessity of finding that that wealth is no more justifiable than race as a criterion in order to make a determination of functional equivalence represents a departure from Professor Fiss's theory. See note 43 supra.

102 In Chicago, the locus of Gautreaux v. Chicago Housing Authority, 296 F. Supp. 907, 304 F. Supp. 736 (N.D. Ill. 1969), approximately ninety percent of persons in public housing or on waiting lists were members of racial minorities. In areas in which the percentage is not nearly as high, analysis of patterns approval and disapproval in the referenda may be necessary to determine whether the basis of decision was racial. This is not to imply that the Court has not previously faced such difficulties. On the contrary, the achievement of educational integration, a "unitary nonracial school system," poses similar problems. See Fiss, supra note 69.

103402 U.S. at 141.

104 Fiss, supra note 43, at 296. 
may then determine whether the basis of approval of low-income public housing sites is racial-that is, whether sites are generally approved when located in areas of minority racial concentration and generally disapproved when located in white neighborhoods. This does not mean that motive is relevant. Whatever the motive-racial animosity, concern for property values, or concern about the possibility of higher taxes-the effect may be that members of racial minority groups are excluded from white residential areas, and from this it may be inferred that the basis for approval and disapproval is race.

In Valtierra, neither the district court nor the Supreme Court examined the question of the location of housing sites which were approved and disapproved. The district court did find that "only $52 \%$ of the referenda submitted to voters have been approved"105 in California, but its opinion gave no indication that the court examined or compared the racial character of the neighborhoods in which the proposed sites were approved and disapproved. In Gautreaux v. Chicago Housing Authority, ${ }^{108}$ however, in which a federal district court ordered the Chicago Housing Authority to build most of its future projects in white neighborhoods, such an examination was made. The court found that the proposed sites in white neighborhoods were generally vetoed and that the proposed sites in black neighborhoods were generally approved.

The impact of Valtierra on the validity of the district court's ruling in Gautreaux is not clear. The cases are similar in many respects. In both, the local housing authority's selection of a public housing site was subject to the veto power of an "outside agency." In Gautreaux the veto was exercised by the alderman of the ward in which the proposed site was located, while in Valtierra it was exercised by the community in which the proposed site was located. In Gautreaux the court found no evidence that either the housing authority or the alderman was motivated by racial animus. ${ }^{107}$ Regardless of motive, the effect of the site selection procedure was racially discriminatory: "[N]o criterion, other than race, [could] plausibly explain the veto of over $991 / 2 \%$ of the housing units located on the white sites ... and at the

105313 F. Supp. at 3.

106296 F. Supp. 907, 304 F. Supp. 736 (N.D. Ill. 1969).

107 Defendants urge that [Chicago Housing Authority] officials never entertained racist attitudes and that the racial character of the neighborhood has never been a factor in CHA's selection of a suitable site. . . [T] [Tese statements are undoubtedly true. It is also true that there is no evidence that the Aldermen who vetoed the white sites were necessarily motivated by racial animus when they followed a policy of keeping Negroes out of white neighborhoods.

296 F. Supp. at 914. 
same-time the rejection of only $10 \%$ or so of the units on Negro sites." 108 This showing was sufficient to bring the aldermanic veto within the prohibition of the equal protection clause.

If these same Chicago communities were to adopt a mandatory referendum on low-income public housing site selection and the same pattern of approval and disapproval of proposed sites were to emerge, there is little doubt that the Gautreaux court would invalidate the referendum procedure-it would not permit communities to achieve the same result through the ballot box which was constitutionally impermissible when accomplished by an aldermanic veto. Thus, the crucial difference between Valtierra and Gautreaux may be merely evidentiary-the proof of effect of the site approval procedure. If the Valtierra Court was unconvinced by the district court's finding of a racially discriminatory effect, the best procedure may have been to simply remand for trial on the merits, where additional facts could have been introduced.

\section{G. Reitman, Hunter, and Valtierra-Are They Consistent?}

The foregoing analysis does not, of course, explain the Supreme Court's disregard of the lower court's findings of racial discrimination, which, according to Reitman, are entitled to great weight. It is thus reasonable to inquire whether Reitman, although not mentioned by the Court, was implicitly overruled.

The lower court in Valtierra found that "[h]ere, as in the Hunter case, the impact of the law falls upon minorities." 109 The Supreme Court summarily dismissed this finding. ${ }^{110}$ Such a modus operandi is contrary to that employed by the Court in Reitman. In that case Proposition 14, an initiative constitutional amendment neutral on its face, had been approved in a statewide referendum by nearly a two-toone margin. The amendment repealed state legislation prohibiting housing discrimination and required that further legislation on the subject be approved in a statewide referendum. In rejecting the petitioners' contention that the amendment was neutral with respect to race, Justice White, writing for the Court, stated that because the Court had been given no persuasive evidence to the contrary, the

108 Id. at 912.

109313 F. Supp. at 5.

110 After noting that the district court had chiefly relied on the Hunter case, the Court stated: "The Court below erred in relying on Hunter to invalidate Article XXXIV. -Unlike the case before us, Hunter rested on the conclusion that Akron's referendum law denied equal protection by placing 'special burdens on racial minorities within the governmental process." " 402 U.S. at 140. 
Galifornia Supreme Court's belief that the provision would "significantly encourage and involve the State in private discriminations" would control.111

Although the lower court in Valtierra made no finding of "encouragement,"112 apparently the Supreme Court gave no weight to the lower court's finding that the referendum provision would impose a special burden on racial minorities-the constitutional standard for invalidity established in Hunter $v$. Erickson..$^{113}$ There a referendum ordinance was passed "amending the city charter to prevent the city council from implementing any ordinance dealing with racial, religious, or ancestral discrimination in housing without approval of the majority of the voters of [the city]."114 The city argued that the challenged provision was valid under Reitman because no finding of "encouragement" had been made by the lower court. The Supreme Court dismissed the argument:

Here, unlike Reitman, there was an explicitly racial classification treating racial housing matters differently from other racial and other housing matters. ...

... Moreover, although the law on its face treats Negro and

111387 U.S. at 381. The somewhat inscrutable opinion of the Court in Reitman has perhaps been most accurately characterized as a "pas de deux with the California high court." Sager, supra note 20, at 790. Justice Harlan, dissenting in Reitman, argued that the Court's decision was premised upon the assumption that the neutrality of the amendment was a sham, and that "[i]n depicting the provision as tantamount to active State encouragement of discrimination the Court essentially relies on the fact that the California Supreme Court so concluded." 387 U.S. at 389-90. Reitman has meant a number of different things to a number of different persons. See, e.g., Black, supra note 20, at 82:

The rule which I would propose, then, as a basis for the Reitman decision, is that where a racial group is in a political duel with those who would explicitly discriminate against it as a racial group, and where the regulatory action the racial group wants is of full and undoubted federal constitutionality, the state may not place in the way of the racial minority's attaining its political goal any barriers which, within the state's political system taken as a whole, are especially difficult of surmounting, by comparison with those barriers that normally stand in the

way of those who wish to use the political processes to get what they want.

According to Karst \& Horowitz, supra note 20, at 51, the Court's opinion "makes clear that it decided the case on the basis of the state's involvement in racial discrimination, and not because of any structural limitation on Negroes' ability to make their influence felt."

112 The meaning of "encouragement" in the Court's opinion is somewhat ambiguous. However, it is perhaps most consistent with the Court's prior opinions, see, e.g., United States v. O'Brien, 391 U.S. 367 (1968), discussed in text at note 73 supra, to adopt the view of Karst \& Horowitz, supra note 20, at 47: "[T]o the extent that the California Court did hold that Proposition 14 was an encouragement of private discrimination, it plainly did so, not by reading a declaration of purpose into the text of Proposition 14, but by measuring the conceded effect of the amendment ...."

113393 U.S. 385 (1969).

114 Id. at 386. 
white, Jew and gentile in an identical manner, the reality is that the law's impact falls on the minority. The majority needs no protection against discrimination and if it did, a referendum might be bothersome but no more than that .... [The ordinance] places special burdens on racial minorities within the governmental process. This is no more permissible than denying them the vote, on an equal basis with others. ${ }^{115}$

The Court concluded that "the State may no more disadvantage any particular group by making it more difficult to enact legislation in its behalf than it may dilute any person's vote or give any group a smaller representation than another of comparable size."116 It is clear that such a special burden might fall on minority groups whether or not an explicit classification is made. The principle of a statute "neutral on its face" gives express recognition to that possibility. This was the finding of the lower court in Valtierra.

It may be possible to distinguish Reitman and Hunter from Valtierra on the ground that the provisions in the former cases repealed substantive rights while the provision in the latter did not. However, several factors preclude such an easy distinction. First, the Supreme Court has never held that states have an obligation to pass fair housing laws. Thus, it can be said that after the passage of Proposition 14 in Reitman the state of California assumed the same position with respect to housing discrimination as states which had never passed fair housing legislation at all. Second, immediately preceding the Hunter decision, the Givil Rights Act of $1968^{117}$ had been enacted and Jones v. Mayer, ${ }^{118}$ prohibiting private housing discrimination, had been decided. Either the Act or the Jones decision would presumably have given a remedy to the Hunter plaintiff. However, the Court dismissed the city's argument that the case had been rendered moot by these events. Third, because public housing projects are probably composed of a racially heterogeneous population, it is difficult to determine whether fair housing laws with respect to these occupants or potential occupants have been repealed by article XXXIV.

It is difficult to reconcile Valtierra with Reitman and Hunter, especially since Reitman was not mentioned in the Valtierra opinions. It is possible, however, to suggest one theory which would permit these cases to be interpreted in a consistent manner: If a statute is neutral on

115 Id. at 389, 391 (emphasis added).

$116 \mathrm{Id}$. at 393.

117 Pub. L. No. 90-284, 82 Stat. 73 (1968).

118392 U.S. 409 (1968). 
its face and the lower court finds that it will "encourage" racial discrimination, the Supreme Court will give great weight to this determination and affirm unless persuasive evidence to the contrary is offered. ${ }^{119}$ If a statute, although treating racial minorities and whites alike on its face, makes an explicitly racial classification whose impact falls upon minorities by imposing special burdens within the governmental process, the Court will invalidate it without requiring a determination of "encouragement" by the lower court.120 If, however, a statute is neutral on its face and the lower court makes a determination that the impact of the law falls upon racial minorities, the Supreme Court will give no weight to the lower court's determination. The matter would thus seem to be one of employing the correct key wordif the statute is neutral, the lower court should use "encouragement" language; if the statute makes an explicitly racial classification, although treating everyone alike, the lower court should use "special burden" language. This theory is supported by the Court's language in Palmer v. Thompson:121

Petitioners also claim that Jackson's closing of the public pools authorizes or encourages private pool owners to discriminate on account of race and that such "encouragement" is prohibited by Reitman v. Mulkey ....

... This Court there accepted what it designated as the holding of the Supreme Court of California....

In the first place there are no findings here about any state "encouragement" of discrimination, and it is not clear that any such theory was ever considered by the District Court. ${ }^{122}$

The Supreme Court seems to have implied that had the lower court made a finding of "encouragement" with respect to Jackson's neutral act of closing its pools, a different question would have been presented. Both the elements of "encouragement" and "special burden" were arguably present in both Reitman and Hunter as well as in Valtierra. ${ }^{123}$ If the explanation offered for reconciling the cases seems strained,

119387 U.S. 369 (1967).

120393 U.S. 385 (1969).

121403 U.S. 217 (1971).

122 Id. at 223.

123 Proposition 14 clearly imposed "a special burden" upon minorities seeking to pass fair housing legislation. The effect of repealing the fair housing ordinance in Hunter and prohibiting the enactment of future fair housing legislation except by referendum would arguably "encourage" discrimination within the meaning of Reitman, although the Hunter court chose not to rely upon the "encouragement" standard in favor of the more traditional equal protection approach of increased procedural burden. 
perhaps the only alternative explanation is that they cannot be read together and that Valtierra implicitly overruled Reitman. ${ }^{124}$

\section{CONCLUSION}

The result reached by the Valtierra Court is satisfying because in an era of growing federal bureaucracy it leaves to popular resolution a decision which may vitally affect local communities. Yet the decision is also unsatisfying because it exacerbates the isolation of the poorespecially the minority group poor long subjected to discrimination because of race-within the inner city. In sum, Valtierra may be more important for what it failed to say than for what it did say and do. For by ignoring the important questions raised by the plaintiff with respect to evolving doctrines of the equal protection clause, the Court may have signaled a retreat from its formerly expansive interpretations of the fourteenth amendment.

Donna M. Murasky

124 Another approach is, of course, to limit Reitman or Valtierra to its specific factsto say that constitutional principles apparently enunciated in either case have no application to any other case. 